\title{
Pilot-project of implantation of pharmaceutical care close to the program of bipolar mood disorder of the Hospital of Clinics of Porto Alegre
}

\author{
Keila Maria Mendes Ceresér*1,2, Marcello Ávila Mascarenhas', Aida Santin², Flávio Kapczinski ${ }^{1,2}$ \\ ${ }^{1}$ Molecular Psychiatry Laboratory, Hospital of Clinics of Porto Alegre, ${ }^{2}$ Clinic of the Program of Bipolar Mood Disorder of the \\ Hospital of Clinics of Porto Alegre
}

\begin{abstract}
The Bipolar Mood Disorder is characterized by the alternation of depressive crises with episodes of mania or euphoria, having these patients 15 to 35 times more chances of suicide, as compared with people without this disorder. The pharmacotherapy is fundamental for this disease, aiming to decrease the frequency of episodes and disease severity. In these patients, the polypharmacy has recently increased and one of the main difficulties is the adherence to treatment. The objective of this study was to contribute for the improvement of bipolar patients health conditions, developing their respective pharmacotherapeutic follow-up. Twenty eight adult bipolar patients who were participants of a specialized clinic within a tertiary hospital in Porto Alegre have been randomly selected, and the Dader Method of pharmacotherapeutic follow-up has been applied. The more common clinical comorbidities were: hypertension (50\%), obesity (46.43\%), and hypothyroidism (36.29\%). The bipolar patients are more susceptible to clinical comorbidities, and many of them could be due to pharmacotherapy. Only $1.43 \%$ of patients presented Drug Related Problems, being all of them resolved along the study. It was also observed that $32.14 \%$ of evaluated patients presented low adherence to treatment, and between these patients, $55.56 \%$ passed to have good adherence after pharmacotherapeutic follow-up. The pharmacotherapeutic follow-up is fundamental for the improvement of patient's health. New studies, with higher number of patients and longer duration, are necessary to evaluate the percentage of patients that could be beneficiary of Pharmaceutical Care.
\end{abstract}

Uniterms: Pharmaceutical Care. Bipolar Mood Disorder. Pharmacotherapy.

O Transtorno do Humor Bipolar é caracterizando pela alternância de crises depressivas com episódios de mania ou euforia, tendo estes pacientes $15-35$ vezes mais chances de suicídio em comparação com pessoas sem este transtorno. A farmacoterapia é fundamental, visando diminuir a freqüência dos episódios e a gravidade da doença. Nestes pacientes, a polifarmácia tem aumentado ultimamente e uma das maiores dificuldades é a adesão ao tratamento. O objetivo do estudo foi contribuir para a melhoria das condições de saúde de pacientes bipolares, realizando o acompanhamento farmacoterapêutico dos mesmos. Foram selecionados aleatoriamente 28 pacientes bipolares adultos, participantes de um ambulatório especializado de um hospital terciário em Porto Alegre e aplicado o Método Dáder de acompanhamento farmacoterapêutico. As co-morbidades clínicas mais comuns foram: hipertensão (50\%), obesidade $(46,43 \%)$ e hipotiroidismo (39,29\%). Os pacientes bipolares são mais suscetíveis a co-morbidades clínicas e muitas destas podem ser devidas a farmacoterapia. Apenas 1,43\% dos pacientes apresentavam Problemas Relacionados a Medicamentos, sendo todos solucionados no decorrer do estudo. Também se observou que $32,14 \%$ dos pacientes avaliados apresentavam baixa adesão ao tratamento e entre estes, $55,56 \%$ passaram a ter boa adesão após o acompanhamento farmacoterapêutico. É fundamental para a melhoria da saúde do paciente o acompanhamento farmacoterapêutico. Novos estudos, com maior número de pacientes e maior duração, são necessários para avaliar o percentual de pacientes que poderão ser beneficiados pela Atenção Farmacêutica.

Unitermos: Atenção farmacêutica. Transtorno do Humor Bipolar. Farmacoterapia.

\footnotetext{
*Correspondence: K. M. Ceresér. Hospital de Clínicas de Porto Alegre, Laboratório de Psiquiatria Molecular. Rua Ramiro Barcelos, 2350 - Centro de Pesquisas - $1^{\circ}$ andar - 90035-003 - Porto Alegre - RS, Brasil. E-mail: keila. cereser@uol.com.br
} 


\section{INTRODUCTION}

The utilization of medications is a complex process, with many determinants, and the adequate pharmacotherapeutic guidelines for the clinical condition of an individual are essential elements for the determination of medications employment. However, it is important to remember that the prescription and use of medications are influenced by factors of cultural, social, economical and political nature (Perini et al., 1999; Faus, 2000).

The morbimortality related to medications is a relevant public health problem and a determinant of hospital internments, which could be attributed to drug activity, therapeutic failures, non-adherence to treatment, and adverse events (Johnson, Bootman, 1995; Easton et al., 1988; Roughead et al., 1998; Malhotra et al., 2001). The traditional models of pharmaceutical practice have shown little effectiveness respecting to morbimortality related to medications (Cipolle et al., 2000). The prevalence and costs of morbimortality related to medications are relevant for the health systems managers, patients and society as a whole (Johnson, Bootman, 1995; Malhotra et al., 2001).

The main causes of preventable morbidity related to medications are: inadequate prescription, unexpected adverse reactions to medications, non-adherence to treatment, overdose or subdose, lack of necessary pharmacotherapy, inadequate follow-up of signals and symptoms, and medication errors (Hennessy, 2000; Hepler, 2000).

According Hepler (2000), the preventable morbidity related to medications must be controlled through the following strategies: a) increase of population and health professionals conscience about the problem; $b$ ) development and dissemination of control strategies for the health programs; c) identification and determination of problems relationship involving medication utilization in the population; d) provision of means to resolve or avoid the evolution of problems; e) improvement of medications utilization criteria.

The Pharmaceutical Care (PC) is an alternative that looks to improve the process quality of medications utilization, reaching positive results. Roughead et al. (1998) published a review in which they demonstrate that rates of hospital internments related to medications corresponded to $2-4 \%$ of total hospital internments, $6-7 \%$ of emergency admissions, $12 \%$ of admissions in medical clinic units, and $15-22 \%$ of admissions in emergencies of geriatrics.

In 2002, Winterstein et al. published a metanalysis respecting hospital internments related to medications, demonstrating that their prevalence could vary between $3-9 \%$ of hospital internments, and a percentage over $50 \%$ of such internments could be prevented.
The quality of life improvement in patients with cardiac failure, diabetes, hypertension, and dyslipidemia, occurring as a consequence of Pharmaceutical Care, was demonstrated by Jaber et al. (1996). Hepler (2000) has also developed a project to evaluate Pharmaceutical Care in asthmatic patients; in Europe, works showing the positive impact of Pharmaceutical Care in asthma have also been developed (Gourley et al., 1998; Hepler, 2000). Kaboli et al. (2006) published a systematic review, describing positive findings referring to activities of clinical pharmacists working within hospital teams.

The practice of $\mathrm{PC}$ requires the pharmacist cooperating with the patient and other healthcare professionals, having as his main role the identification of existing or potential Drug Related Problems (DRP) and, respectively, their resolution or prevention (Hepler, Strand, 1990; Hepler, 1993; OMS, 1993; Kaboli et al., 2006).

According to the committee of the Second Consensus of Granada on Drug Therapy Problems (2002), the DRP could be classified into three groups: necessity problems (when the patient makes use of an unnecessary medication, or when he/she does not utilize a necessary medication); effectiveness problems (when the utilized medication does not promote the desired effect, being it or not a dose-dependent result); safety problems (when the patient utilizes a medication that is not being safe, either due to utilization of a very high dose, or thanks to appearance of adverse reactions, irrespectively of utilized dose).

A study developed by Crockett et al. (2006), suggests that the pharmacist's involvement could be beneficial to treatment of patients with unipolar depression. There are no specific works describing the pharmaceutical orientation to bipolar patients.

The Bipolar Mood Disorder (BMD) is a chronic and recurrent disease affecting $1-5 \%$ of population. It is characterized by the alternation of depressive crises with episodes of mania or euphoria and it is classified into two categories: Type I disorders and Type II disorders. The Type I BMD presents an entire amplitude of mood variation, from the higher peak (full mania), which could last for several weeks, up to severe depressions. Generally, it starts in the age range between 15 and 30 years, and commonly presents psychotic symptoms or hallucinations. In the Type II BMD, the maniac phase is gentler and short, being called hypomania and the depressions could be deeper. They could start in the adolescence, with mood oscillation, but a part of patients only express the depressive phase around the age of 40 years. Frequently, the mood symptoms lay aside their pronounced nature of a single pole, to exhibit mixed characteristics (DSM-IV TR, 2000). The bipolar patients are of difficult diagnosis, mainly 
in the initial course of their disease, because they could present only depressive symptoms and manifest a maniac episode only after years. The diagnosis veracity is determinant for the effectiveness of pharmacologic treatment (Schou, 1999; Keck, 2003; Gazalle et al., 2005). The bipolar disorders are common and recurrent, bringing huge socio-economic damages to patients and society, such as absenteeism and excessive expenses. Besides, these patients present 15 to 35 times more chances of suicide, as compared with people without this disorder (Burgess et al., 2002).

In view of disease severity, the pharmacologic treatment is fundamental and aims to decrease the frequency of episodes, the disease severity, and improve the psycho-social consequences (Guscott, Taylor, 1994; Sproule, 2002). The concomitant use of several drugs for the treatment of BMD has increased in the late years (Gazalle et al., 2007), and one of the major difficulties in the treatment of these patients is the adherence to treatment. It was developed a review respecting treatment adherence in bipolar patients (Santin et al., 2005), where factors linked to medications (undesired effects, drug interactions, complex regimen), factors linked to patient (cognitive alterations, knowledge about the disease, personality), and factors linked to physician (interaction with patients) were verified as possible cause for the low adherence.

The lithium is the mood stabilizer of choice for the treatment of bipolar patients, because it is effective in the acute crises and along treatment maintenance, besides to be the single drug with anti-suicide action (Schou, 1999).

The individuals bearing BMD have their everyday significantly affected in a negative way, to the point of damage their social and professional interrelationships; such problems could be softened, and in some cases even cured, when these individuals follow correctly the prescribed therapeutic plan (Iñesta, 2000). This affirmation reinforces the importance of a pharmacotherapeutic follow-up developed by a pharmacist professional, who shall monitor the therapeutic regimen and, if necessary, jointly with the physician, review the regimen respecting the progresses, positive results reaching, and treatment effectiveness (Iñesta, 2000).

Another positive point of PC, when applied to psychiatric disorders, is the education of patients, their relatives, and coexisting people (Juruena, Vieira, Busnello, 2000). The education is an essential component of the combined treatment of BMD, as several clinical studies have already demonstrated. The psycho-social intervention during the maintenance treatment has been recognized as an important tool to stimulate treatment adherence, in patients with BMD (APA, 2002).
The successfully tested psychological interventions contemplate classical psycho-educative elements, such as to improve the insight respecting the disease, to deal with stigmatization, to improve treatment adherence, and to teach the patient and his family to identify early prodromal signals, to promote healthy habits and the lifestyle regularity, and avoid substances abuse (Colom, Vieta, 2004).

The Pharmaceutical Care is a model of professional practice developed by the pharmacist, in which this professional jointly with the remaining members of the health team, identifies, evaluates, and look to resolve the DRP.

The objective of this study was to contribute for the improvement of health conditions of bipolar patients, developing their respective pharmacotherapeutic followup. This work is part of a research project that count on the support of $\mathrm{CNPq}$, in the pharmaceutical care area, and it was developed between 2006 January and 2007 June.

\section{METHODS}

Twenty eight adult patients were randomly selected (21 women and 07 men), bearers of Bipolar Mood Disorder (BMD), participants of the Bipolar Mood Disorder Program from the Hospital of Clinics of Porto Alegre (Programa de Transtorno do Humor Bipolar do Hospital de Clínicas de Porto Alegre - PROTAHBI-HCPA). The distribution of the investigated sample respecting to gender was the same as that in the studied population.

It was applied the Dader Method of pharmaceutical follow-up, developed by the Pharmaceutical Care investigation group of the University of Granada, in 1999 (Machuca, Fernández-Llimós, Faus, 2003, Dader, Muñoz, Martinez-Martinez, 2008). According this methodology, the pharmacotherapeutic follow-up is composed by the following steps: first interview, situation status, study and evaluation phase, intervention, interventions results, and new situation status.

Before the first interview, every patient was contacted, personally or by phone, when it was explained the methodology and scheduled the first interview, occasion in which the patient should bring a bag with all medications utilized by him, including those used only occasionally or by self-medication.

The first interview was developed in a place in which the patient felt himself at ease; when he exposed his current and previous health problems, without any intervention from the pharmacist. In a second moment of this interview, the pharmacist evaluated some of the information provided by the patient, requesting more detail as well as fulfilling a detailed card respecting his currently used medications, in which, for every medication taken, 
the patient should answer: who prescribed it, for what reason, if he was feeling better, since when he was utilizing it, how much medication was he using per day, how was he using it, until when should he utilize it, and if he was feeling something strange or some difficulty related to that medication.

The pharmacist observed and noted details respecting the patient's knowledge about the medication and respecting his adherence to it. The patient was also asked respecting the previously used medications, and the reason for their suspension.

To finish this first interview, the pharmacist did a revision, relating all body parts, letting the patient report the problems found. He also asked about the patient's lifestyle, as alcohol consumption, smoking habits, drugs use, nurture habits; coffee, teas or "mate" consumption, and sedentarism. This first interview had an average duration of two hours, occasion in which it were also applied scales for evaluation of probable depression or mania, respectively Hamilton Depression (HAM-D) and Young Mania Rating Scale (YMRS), being also checked the weight, height, and signed the 'Informed Consent Form' (ICF). It was considered as maniac or depressed the patient presenting scores higher or equal to 7, respectively, in the scales HAM-D and YMRS. The individuals totalizing scores lower than 7 in both scales, were considered as euthymic.

After the first interview, it was elaborated the patient's first situation status, in which were described the probable relationships between health problems and medications.

In the following phase of studies and evaluation, it was developed a consultation in the patient's history and a talk with his personal psychiatrists occurred, besides a search by the investigators, for explanations to possible DRP in the medical literature.

In the intervention phase (normally, one month after the initial interview), firstly the evaluation results were presented to the clinical team, in order to develop the necessary interventions. It was then scheduled a second pharmaceutical consultation, in which the patient was clarified about DRP and received orientation about the rational use of medications and improvement of his lifestyle.

During the intervention phase, the pharmacists developed the medical history research, and subsequently they discussed with the responsible physicians. Then, every case was discussed in a clinical meeting with the multidisciplinary team and, lastly, the conduction to be followed by the patient was presented to him by the pharmacists, verbally and in writing, as well as to the responsible physician, who usually was in charge of highlight the importance of pharmacotherapeutic follow-up to the patient, including as a note into patient's history, the development of pharmaceutical care.

After six months from the intervention phase, it was determined the result obtained for the resolution of the detected health problem, and formulated a new situation status, where the changes occurred in the health problems and pharmacological treatment after the intervention, were analyzed. Again, the patient was evaluated by scales of depression and mania.

\section{RESULTS AND DISCUSSION}

The patients with BMD are normally polymedicated (Zarate, Quiroz, 2003; Gazalle et al., 2007) and use, as an average, $6.3 \pm 2.9$ medications, being $2.6 \pm 0.8$ psychiatric (Table I). Along the study, after the first interview, a loss has occurred, due to patient's death. This patient was bearer of Acquired Immunodeficiency Syndrome (AIDS), in severe condition, associated to a picture of bacterial pneumonia.

Only four patients (1.4\%) presented DRP (Table II), being all of them resolved along the study. Between these four patients, three had problems of drug interaction, out of which two patients utilized medication for treatment of hypothyroidism joined to food. These occurrences were classified as DRP of effectiveness. The other patient presented an interaction between the antibiotic norfloxacin and lithium, being classified as a DRP of safety. After the oral and in writing interventions, it was observed the problem resolution at the pharmaceutical care of the new situation status.

A patient has not adapted himself to medication undesired effects, presenting a strong gastric illness with carbamazepine; so the medical team was contacted and a subsequent alteration of mood stabilizer prescription to lithium associated to valproate was done. In this case, it was observed a DRP linked to medication safety, which was already resolved at the moment of the new situation status.

The low frequency of DRP could be explained by the fact that these patients had constant follow-up from the health team; being also observed that the individuals did not present use of unnecessary medications. It was also observed that nine $(32.1 \%)$ evaluated patients presented problems related to low adherence to treatment, which could result in DRP, and between the motives for this low adherence, the following were reported: fear of undesired effects, the fact that the patient was feeling well, and a "pause for intake of alcohol". These individuals were advised to change their conduct, in order to prevent probable DRP related to low adherence.

Between the patients with problems of adherence 
TABLE I - More utilized medications

\begin{tabular}{lc}
\hline *Drugs & $\mathrm{n}(\%)$ \\
\hline acetylsalicylic acid & $07(25)$ \\
valproic acid or derivatives & $12(42.9)$ \\
Non-steroidal anti-inflammatory drugs & $02(7.1)$ \\
amlodipine & $01(3.6)$ \\
atenolol & $01(3.6)$ \\
biperidene & $03(10.7)$ \\
Sympathomimetic bronchodilators & $03(10.7)$ \\
bupropion & $02(7.1)$ \\
carbamazepine & $06(21.4)$ \\
lithium carbonate & $19(67.9)$ \\
carisoprodol & $02(7.1)$ \\
cimetidine & $01(3.6)$ \\
citalopram & $01(3.6)$ \\
claritidine & $01(3.6)$ \\
clonazepam & $05(17.9)$ \\
clozapine & $01(3.6)$ \\
corticoids & $03(10.7)$ \\
tiazidic diuretics & $07(25)$ \\
doxasozine & $01(3.6)$ \\
phenothiazines & $12(42.9)$ \\
fluoxetine & $03(10.7)$ \\
haloperidol & $01(3.6)$ \\
Angiotensin-Converting Enzyme Inhibitors & $07(25)$ \\
insulin & $01(3.6)$ \\
ipratropium & $01(3.6)$ \\
lamotrigine & $01(3.6)$ \\
levothyroxine & $11(39.3)$ \\
metformin & $05(17.9)$ \\
olanzapine & $02(7.1)$ \\
omeprazol & $04(14.3)$ \\
paracetamol & $15(53.6)$ \\
propranolol & $05(17.9)$ \\
risperidone & $05(17.9)$ \\
sulpiride & $02(7.1)$ \\
topiramate & $01(3.6)$ \\
valsartan & $01(3.6)$ \\
vastatins & $04(14.3)$ \\
\hline Mouliple respon & \\
&
\end{tabular}

* Multiple responses

to treatment, five (55.6\%) passed to have good adherence after the pharmacotherapeutic follow-up. On occasion of the first evaluation, eighteen $(64.3 \%)$ patients were euthymic (scores lower than 7 in the scales HAM-D and YMRS) and the remaining ones were depressed (scores equal or higher than 7 in the scale HAM-D), and at the end of follow-up, sixteen (57.1\%) patients were in euthymia, being that these patients who suffered mood alterations during the follow-up were between those with unresolved adherence problems. Fifteen (53.6\%) between the twenty eight followed-up patients had already passed by, at least, one psychiatric internment, being that during the followup only one patient (3.6\%) was hospitalized, presenting as cause the maniac status (YMRS $\geq 7$ ). Eleven followedup patients $(39.3 \%)$ had already attempted, at least once, suicide; and during the follow-up no patient had a suicide attempt.

Figure 1 presents the clinical comorbidities exhibited by studied patients, where the most commonly observed ones were: hypertension (50\%), obesity (46.4\%), hypothyroidism (39.3\%), and gastric problems (32.1\%). It is known that bipolar patients are more susceptible to clinical comorbidities (Angst et al., 2000) and many of these could be due to utilized medications, such as hypothyroidism (Bocchetta et al., 2007) and obesity (Ketter, Haupt, 2006; Garcia-Portilla et al., 2008). It is also known that lithium and valproate could lead to hypothyroidism, and that mood stabilizers and antipsychotics could lead to obesity. Besides these variables, there are several other factors; it is known that BMD is associated to an increase of morbimortality for general clinical conditions, such as cardiovascular diseases, obesity, metabolic syndrome, diabetes, dyslipidemia, hypertension, inflammatory diseases and age, between other contributing for these outcomes (Cunha et al., 2008).

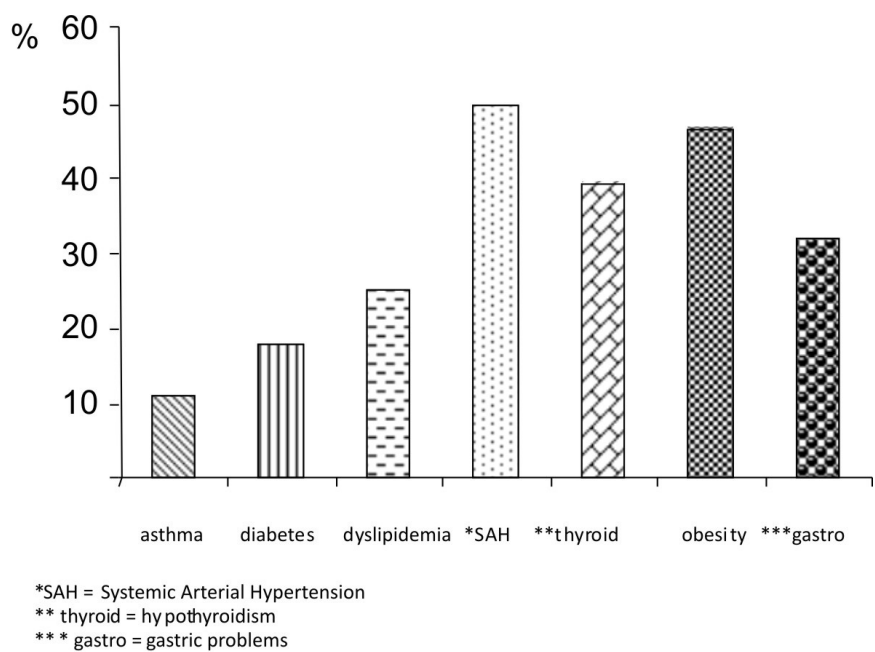

FIGURE 1 - Frequency of clinical comorbidities.

\section{CONCLUSIONS}

The pharmacist participates actively of the improvement process of BMD patient, in a multi-professional team, dividing and changing information with all involved professionals. It is possible to observe, by the DRP resolution, the importance of pharmacotherapeutic follow-up for the improvement of patient's health. It is fundamental that he- 
TABLE II - Risk for DRP associated to occurrence of drug interactions

\begin{tabular}{lclc}
\hline Medications & $\mathrm{n}$ & Effect & $\begin{array}{c}\text { DRP } \\
\text { Classification } \\
\text { (N, E, S)* }\end{array}$ \\
\hline Levothyroxine and food & 2 & Levothyroxine can have its absorption decreased in the presence of food & $\mathrm{E}$ \\
Lithium and Norfloxacin & 1 & Lithium can have its serum levels increased in the presence of norfloxacin & $\mathrm{S}$ \\
Carbamazepine & 1 & Some patients present gastric problems with the use of carbamazepine & $\mathrm{S}$ \\
\hline
\end{tabular}

*N: necessity, E: effectiveness, S: safety

alth professionals working directly with psychiatric patients become conscious about the importance of the orientation respecting the disease, the medications and all other forms of prescribed treatments, to be given to patients and their relatives. New studies, with higher number of patients and longer duration, are necessary to evaluate the percent of patients that could be effectively benefited by PC.

\section{ACKNOWLEDGMENT}

This work was supported by CNPq (Edictal 54/2005).

\section{REFERENCES}

ANGST, J. Historical perspectives and natural history of bipolar disorder. Biol. Psych., v.48, n.6, p.445-457, 2000.

APA. American Psychiatric Association. Practice Guidelines for the treatment of patients with bipolar disorder (revision). Am. J. Psychiatry, v. 159, n.4, p.1-50, 2002.

BOCCHETTA, A., COCCO, F., VELLUZZI, F., DEL ZOMPO, M., MARIOTTI, S., LOVISELLI, A. Fifteen-year followup of thyroid function in lithium patients. J. Endocrinol. Invest., v.30, n.5, p.363-366, 2007.

BURGESS, S., GEDDES, J., HAWTON, K., TOWNSEND, E., JAMISON, K., GOODWIN, G. Lithium for maintenance treatment of mood disorders (Cochrane Review). Cochrane Database Syst. Rev., v.4, p.1-35, 2002.

CIPOLLE, D. J., STRAND, L. M., MORLEY, P. C. El ejercicio de la atención farmacéutica. Madrid: McGraw-Hill Interamericana, 2000. $352 \mathrm{p}$.

COLOM, F., VIETA, E. Melhorando o desfecho do transtorno bipolar usando estratégias não farmacológicas: o papel da psicoeducação. Rev. Bras. Psiquiatr., v.26, Supl.3, p. 47-50, 2004.
COMITÉ DE CONSENSO. Segundo consenso de Granada sobre problemas relacionados con medicamentos. Ars Pharm., v. 43, n.3-4, p.175-184, 2002.

CROCKETT, J.; TAYLOR, S.; GRABHAM, A.; STANFORD P. Patient outcomes following an intervention involving community pharmacists in the management of depression. Aust. J. Rural Health., v.14:, p.263-269, 2006.

CUNHA, A.B.; ANDREAZZA, A.C.; GOMES, F.A.; FREY, B.N.; DA SILVEIRA, L.E.; GONÇALVES, C.A.; KAPCZINSKI, F. Investigation of serum high-sensitive C-reactive protein levels across all mood states in bipolar disorder. Eur. Arch. Psychiatry Clin. Neurosci., v.258, n.5, p.300-304, 2008.

DADER, M.J.F.; DA SILVEIRA, L.E.; GONÇALVES, C.A.; KAPCZINSKI, F.; MUÑOZ, P.A.; MARTINEZMARTINEZ, F. Atenção Farmacêutica. Conceitos, processos e casos práticos. São Paulo: RCN, 2008. 233p.

AMERICAN PSYCHIATRIC ASSOCIATION- DSM-IV TR. Diagnostic and statistical manual of mental disorders. 4.ed. Washington: American Psychiatry Press, 2000. 880p. (Text revised).

EASTON, K. L.; BARRY, T. P.; STARR, M. S.; BRIEN, J. E. The incidence of drug related problems as a cause of hospital admission in children. MJA, v.169, n.7, p.356-359, 1998.

FAUS, M. J. Atención Farmacéutica como respuesta a una necesidad social. Ars Pharm., v.41, n.1, p.137-143, 2000.

GARCIA-PORTILLA, M. P.; SAIZ, P. A.; BENABARRE, A.; SIERRA, P.; PEREZ, J.; RODRIGUEZ, A.; LIVIANOS, L.; TORRES, P.; BOBES J. The prevalence of metabolic syndrome in patients with bipolar disorder. J. Affect Disord., v.106, n.1-2, p.197-201, 2008. 
GAZALlE, F.; ANDREAZZA, A. C.; CERESÉR, K. M.; HALLAL, P. C.; SANTIN, A.; KAPCZINSKI, F.; CERESÉR, K. M. Clinical impact of late diagnose in bipolar disorder. J Affect Disord., v.86, n.2-3, p.313-316, 2005.

GAZALLE, F.; HALLAL, P. C.; TRAMONTINA, J., ROSA, A. R.; ANDREAZZA, A. C.; ZANATTO, V.; SANTIN; A.; KAPCZINSKI, F.; CERESÉR, K. M. Polypharmacy and suicide attempts in bipolar disorder. Rev. Bras. Psiq., v.29, n.1, p.35-38, 2007.

GOURLEY, D. R.; GOURLEY, G. A.; SOLOMON, D. K.; PORTNER, T. S.; BASS, G. E.; HOLT, J. M.; BRADEN, R. L.; RAWLS, N.; WICKE, W. R.; OGDEN, J.; LAWRENCE, B. Development, implementation and evaluation of a multicenter pharmaceutical care outcomes study. J. Am. Pharm. Assoc., v.38, n.5, p.567-573, 1998.

GUSCOTT, R.; TAYLOR, R. Lithium prophylaxis in recurrent affective illness. Efficacy, effectiveness and efficiency. $\mathrm{Br}$. J. Psychiatry, v.164, n.6, p.741-746, 1994.

HEPLER, C. D.; STRAND, L. M. Opportunities and responsibilities in the pharmaceutical care. Am. J. Health Syst. Pharm., v.47, n.3, p.533-543, 1990.

HEPLER, C. D. Issues in implementing pharmaceutical care. Am. J. Health Syst. Pharm., v.50, n,88, p.1635-1641, 1993.

HEPLER, C. D. Observations on the conference: A pharmacist's perspective. Am. J. Health Syst. Pharm., v.57, n.6, p.590594, 2000.

HENNESSY, S. Potentially remediable features of the medication - use environment in The United States. Am. J. Health Syst. Pharm., v.57, n.6, p.543-547, 2000.

IÑESTA, G. A. Investigación en Atención Farmacéutica. Libro de actas del I Congreso Nacional de Atención Farmacéutica. San Sebastián: Colegio Oficial de Farmacéuticos de Guipúzcoa, 2000. 393p.

JABER, L. A.; HALAPY, H.; FERNET, M.; TUMMALAPALLI, S.; DIWAKARAN, H. Evaluation of a pharmaceutical care model on diabetes management. Ann. Pharmacother., v.30, número?, p.238-243, 1996.

JOHNSON, J. A.; BOOTMAN, J. L. Drug related morbidity and mortality: a cost of illness model. Arc. Intern. Med. v.55, n.18, p.1949-1956, 1995.
KABOLI, P. J.; HOTI, A. B.; MCCLIMON, B. J.; SCHNIPPER, J. L. Clinical pharmacists and inpatient medical care: a systematic review. Arch. Intern. Med., v.166, p.955-964, 2006.

KECK, E. P. Long-term therapy of bipolar illness. Curr. Psyc., v.3, supl.3, S18-S21, 2003.

KETTER, T. A.; HAUPT, D. W. Perceptions of weight gain and bipolar pharmacotherapy: results of a 2005 survey of physicians in clinical practice. Curr. Med. Res. Opin., v.22, n.12, p.2345-2353, 2006.

MACHUCA, M.; FERNÁNDEZ-LLIMÓS, F.; FAUS, M. J. Método Dáder. Guia de seguimento farmacoterapêutico. Granada: Universidad de Granada, 2003. 43p.

MALHOTRA, S.; JAIN, S.; PANDHI, P. Drug related visits to the medical emergency department: a prospective study from India. Int. J. Clin. Pharmacol. Ther., v.39, n.1, p.1218, 2001.

OMS. ORGANIZACIÓN MUNDIAL DE LA SALUD. El papel del farmacéutico en el sistema de atención de salud. Tokio: OPS/HSS/HSE/95.1, 1993.

PERINI, E.; MODENA, C. M.; RODRIGUES, R. N.; NASCIMENTO, R.; MACHADO, A. M. L. E.; PAIXÃO, H. H. Consumo de medicamentos e adesão às prescrições: objeto e problema de epidemiologia. Rev. Cien., Farm., v.20, n.2, p.471-488, 1999 .

ROUGHEAD, E. E., GILBERT, A. L., PRIMOROSE, J. G.; SANSON, L. N. Drug related hospital admissions: a review of Australian studies published 1988-1996. MJA, v.168, n.8, p.405-408, 1998.

SANTIN, A.; CERESÉR, K. M.; ROSA, A. Adesão ao tratamento no transtorno bipolar. Rev. Psiquiat. Clin., v.32, supl.1, p.105-109, 2005.

SCHOU, M. Perspectives on lithium treatment of bipolar disorder: action, efficacy, effect on suicidal behavior. Bipolar Disord., v.1, n.1, p.5-10, 1999.

SPROULE, B. Lithium in bipolar disorder: Can drug concentrations predict therapeutic effect? Clin. Parmacokinet., v.41, n.9, p.639-660, 2002. 
WINTERSTEIN, A. G.; SAUER, B. C.; HEPLER, C. D.;

POOLE, C. Preventable drug related hospital admission.

Ann. Pharmacother., v.36, n.7-8, p.1238-1248, 2002.
ZARATE, C. A.; QUIROZ, J. A. Combination treatment in bipolar disorder: a review of controlled trials. Bipolar Disord., v. 5, n.3, p.217-225, 2003.

Received for publication on $04^{\text {th }}$ march 2008 Accepted for publication on $24^{\text {th }}$ march 2008 